\title{
Left Atrial Appendage Function Assessment by Tissue Doppler Transesophageal Echocardiography in Acute Ischemic Stroke Patients
}

\author{
Tamer Abdel Mawla ${ }^{1 *}$ (D) Osama Momtaz ${ }^{1}$, Mohamed Abdel Gayed ${ }^{1}$, Gomaa Abdelrazek $^{2}$ \\ ${ }^{1}$ Department of Critical Care, Faculty of Medicine, Fayoum University, Faiyum, Egypt; ${ }^{2}$ Department of Cardiology, Faculty of \\ Medicine, Fayoum University, Faiyum, Egypt
}

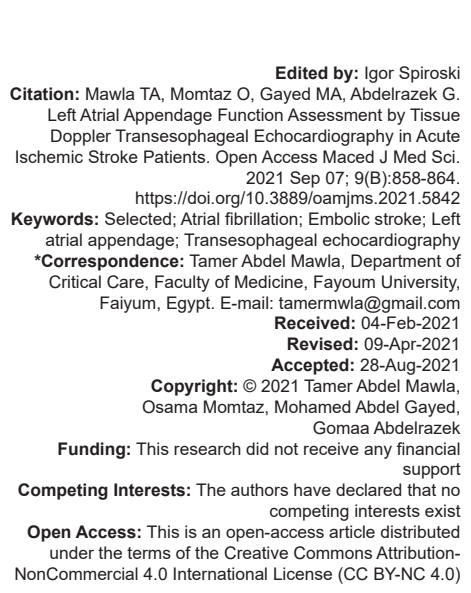

\section{Background}

Stroke is a very important reason for longterm disability and mortality worldwide. Strokes due to cardioembolic causes are the most severe in ischemic stroke subtypes. The stroke incidence has been decreased; however, cardioembolic strokes have increased markedly over the past years. Two-thirds of cardioembolic strokes caused by atrial fibrillation (AF) may be prevented by oral anticoagulation [1], [2], and $A F$ is the major documented reason for cerebral thromboembolism that originate mainly from left atrial appendage (LAA) and difficult to be identified by transthoracic echocardiography (TTE) [3].

Trans-esophageal echocardiography (TEE) is better than TTE for diagnosing probable cardiac embolism sources, without considering age factors. required in:

Echocardiographic assessment is especially 
comprehensive TEE assessment of the LAA evaluation, the LA, left ventricle, and mitral valve should be also assessed formally, with a comprehensive evaluation of LAA shape, contractile function, and Doppler velocities [7]. Tissue Doppler imaging (TDI) should be used in combination with flow velocities for the LAA evaluation. Impaired LAA contractility might be an independent predictor of LAA thrombus [8].

\section{Methods}

This study included 80 patients admitted to the Critical Care Department and Neurology Department from May 2018 to November 2019.

Patients were subdivided into three main groups:

1. Group A: 40 patients with stroke in normal sinus rhythm

2. Group B: 40 patients with stroke in AF

3. Group C (control group): Forty patients with normal sinus rhythm and without stroke who were admitted and subjected to TEE for investigation for other possible diagnoses (e.g. infective endocarditis, masses, and aortic dissection) with no abnormality detected.

\section{Inclusion criteria}

Adult patients with recent ischemic cerebrovascular stroke within seven days of its occurrence.

\section{Exclusion criteria}

- $\quad$ Carotid artery stenosis more than or equal to $50 \%$ diagnosed by carotid duplex

- Esophageal varices or active upper gastrointestinal bleeding or recent esophageal operations

- Hemodynamic instability

- Severe valvular lesions

- Cardiomyopathy.

The following were done for all patients:

- Full medical history, complete physical examination, and laboratory tests

- Assessment of stroke recurrence (new neurological deficit due to vascular insult confirmed by brain imaging)

- $\quad$ Standard 12-leads electrocardiogram

- Brain computed tomography and magnetic resonance imaging for stroke patients

- Bilateral carotid and vertebrobasilar arterial duplex for patients with stroke

\section{TTE}

All patients were subjected to a complete TTE study that was recorded at rest according to the current ASE recommendations by Philips EPIQ-7 machine, with 1.5-4.3 $\mathrm{MHz}$ transducer. The study was done at the left lateral position and ECG leads were attached to define the timing of the cardiac cycle. The following views were obtained; parasternal short and long axes, apical 3, 4, 5, and 2 chambers, and all valves were assessed for regurgitation or stenosis. The following parameters were obtained; left ventricular end-diastolic dimension, EF, mitral valve area, left atrial diameter, pulmonary artery systolic pressure, and regional wall motion abnormality if present.

\section{TEE}

Patients were fasting for 4 hours prior to the study. TEE studies were performed using the same Philips EPIQ-7 machine by $7 \mathrm{MHz}$ probe. Standard TEE views were taken for imaging and assessment of LAA, interatrial septum, mitral and aortic valves, ascending and descending aorta, and aortic arch. Agitated intravenous saline was injected for shunt visualization.

A detailed evaluation of the LAA was performed; in the mid esophageal level, the longest LAA dimension was imaged with the rotation of the sector angle degree from 40 to 90 . The pulsed Doppler sector was aligned parallel to the longitudinally contracting appendage to abolish the necessity for angle correction for the assessment of LAA flow velocities. To reduce the influence of velocity variability during $A F$, the LAA parameters were obtained as the median of three successive beats. Velocities of LAA flow were assessed by positioning the volume sample at $0.5 \mathrm{~cm}$ from the orifice. LAA emptying flow velocity was assessed at maximal upward flow velocity and LAA filling flow velocity was assessed at maximal downward flow velocity.

TDI of the LAA wall motion velocities were measured by adjusting the sample volumes at the medial and lateral walls. Upward velocity represents the highest LAA wall motion velocity moving toward the LAA orifice, while downward velocity represents the highest LAA wall motion velocity moving away from the LAA orifice. The LAA orifice was delineated by a line connecting the aortic valve annulus adjacent to the left coronary artery with the lateral edge of the left superior pulmonary vein.

LAA depth was measured from the LAA orifice to its tip. Ascending aorta and aortic arch atherosclerotic plaques were measured when plaques measure $4 \mathrm{~mm}$ or more this indicates significant atherosclerotic aorta.

\section{Statistical analysis}

Data statistics were mentioned in terms of range, mean \pm standard deviation (SD), the median 
for quantitative variables, frequencies (cases number, and relative frequencies (percentages for categorical variables. Student t-test for non-dependent samples was used to compare quantitative variables between studied groups when normally distributed while Mann Whitney U test was used when not normally distributed. Chi-square $\left(\chi^{2}\right)$ test was used to compare categorical data. Exact test was used instead when the expected frequency is $<5$. Values were considered statistically significant when the probability value ( $p$-value) was $<0.05$. Calculations were performed by Microsoft Excel version XP and SPSS version 19 for Microsoft Windows. The receive operating characteristic curve was used to define the discrimination value of LAA parameters for stroke occurrence and to define optimal cut-points for sensitivity and specificity.

\section{Ethics approval and consent to participate}

Study approval was given from the ethical review committee of our Faculty before the study conduction and every patient was assigned an informed written consent according to the principles of the Local Ethical Committee (Committee reference number: not applicable).

\section{Results}

This study included 80 acute ischemic stroke patients and 40 control patients. Patients were subdivided into three groups (Table 1):

Table 1: Patients' demographic characteristics, stroke risk factors and recurrence

\begin{tabular}{|c|c|c|c|c|c|c|}
\hline \multirow[t]{2}{*}{ Variables } & \multirow{2}{*}{$\begin{array}{l}\begin{array}{l}\text { Group A } \\
(\text { No. } 40)\end{array} \\
\text { Mean } \pm \text { S.D. }\end{array}$} & \multirow{2}{*}{$\begin{array}{l}\text { Group B } \\
(\text { No. 40) } \\
\text { Mean } \pm \text { S.D. }\end{array}$} & \multirow{2}{*}{$\begin{array}{l}\text { Group C } \\
(\text { No. 40) } \\
\text { Mean } \pm \text { S.D. }\end{array}$} & \multicolumn{3}{|l|}{$\mathrm{p}$-value } \\
\hline & & & & $A$ and $B$ & $B$ and $C$ & $A$ and $C$ \\
\hline Age & $62.5 \pm 13.7$ & $63.2 \pm 9.1$ & $58.9 \pm 9.2$ & NS & NS & NS \\
\hline \multicolumn{7}{|l|}{$\operatorname{Sex}(\%)$} \\
\hline Male & $19(47.5)$ & $18(45)$ & $22(55.0)$ & NS & NS & NS \\
\hline Female & $21(52.5)$ & $22(55)$ & $18(45.0)$ & & & \\
\hline Diabetes (\%) & $17(42.5)$ & $28(70.0)$ & $11(27.5)$ & $<0.05$ & $<0.05$ & $<0.05$ \\
\hline Hypertension (\%) & 23 (57.5) & 27 (67.5) & $12(30.0)$ & $<0.05$ & $<0.05$ & $<0.05$ \\
\hline Dyslipidemia (\%) & $30(75.0)$ & $24(60.0)$ & $12(30.0)$ & $<0.05$ & $<0.05$ & $<0.05$ \\
\hline Smoking (\%) & $16(40.0)$ & $14(35.0)$ & $16(40.0)$ & NS & NS & NS \\
\hline $\begin{array}{l}\text { Stroke recurrence } \\
\text { (\%) }\end{array}$ & $5(12.5)$ & $13(32.5)$ & - & $<0.05$ & -- & -- \\
\hline
\end{tabular}

- $\quad \operatorname{Group}(\mathrm{A})$ : included 40 patients with stroke and normal sinus rhythm, 19 males and 21 females and the mean age was $62.5 \pm 13.7$ years

- $\quad$ Group (B): included 40 patients with stroke and $\mathrm{AF}, 18$ males and 22 females and the mean age was $63.2 \pm 9.1$ years

- $\quad$ Group (C) (control group): included 40 patients with normal sinus rhythm and without stroke who had been admitted and subjected to TEE for investigation for other possible diagnoses (e.g. infective endocarditis, masses, and aortic dissection) with no abnormality detected, 22 of them males and 18 females and the mean age was $58.9 \pm 9.2$ years.

The prevalence of diabetes mellitus, hypertension, and dyslipidemia between the three groups of the study was significant but a non-significant difference was detected between the three groups regarding smoking (Table 1 ). It had been found that stroke recurrence was significantly high in Group B (Stroke with AF) than group A (Stroke with sinus rhythm) (Table 1).

\section{Study of LAA parameters by TEE (Table 2)}

Table 2: Study of LAA parameters by TEE

\begin{tabular}{|c|c|c|c|c|c|c|}
\hline \multirow[t]{2}{*}{ Parameters } & \multirow{2}{*}{$\begin{array}{l}\text { Group A } \\
\text { (No. 40) } \\
\text { Mean } \pm \text { S.D }\end{array}$} & \multirow{2}{*}{$\begin{array}{l}\text { Group B } \\
\text { (No. 40) } \\
\text { Mean } \pm \text { S.D }\end{array}$} & \multirow{2}{*}{$\begin{array}{l}\text { Group C } \\
\text { (No. 40) } \\
\text { Mean } \pm \text { S.D }\end{array}$} & \multicolumn{3}{|l|}{$p$-value } \\
\hline & & & & $\bar{A}$ and $B$ & $B$ and $C$ & $A$ and $C$ \\
\hline $\begin{array}{l}\text { Orifice diameter } \\
(\mathrm{cm})\end{array}$ & $1.56 \pm 0.34$ & $1.72 \pm 0.32$ & $1.30 \pm 0.29$ & $\begin{array}{l}0.089 \\
<0.0001\end{array}$ & $<0.0001$ & $<0.001$ \\
\hline Depth $(\mathrm{cm})$ & $2.67 \pm 0.56$ & $2.79 \pm 0.43$ & $2.44 \pm 0.61$ & $\begin{array}{l}0.351 \\
0.015\end{array}$ & $0.004^{*}$ & $0.049^{*}$ \\
\hline $\begin{array}{l}\text { Pulsed wave } \\
\text { emptying velocity } \\
\text { of LAA flow }(\mathrm{m} / \mathrm{s})\end{array}$ & $0.58 \pm 0.23$ & $0.43 \pm 0.16$ & $0.60 \pm 0.20$ & $\begin{array}{l}0.001 \\
0.0003\end{array}$ & 0.005 & 0.919 \\
\hline $\begin{array}{l}\text { Pulsed wave } \\
\text { filling velocity of } \\
\text { LAA flow }(\mathrm{m} / \mathrm{s})\end{array}$ & $0.53 \pm 0.16$ & $0.32 \pm 0.08$ & $0.56 \pm 0.06$ & $\begin{array}{l}<0.0001 \\
<0.0001\end{array}$ & $<0.0001$ & 0.081 \\
\hline $\begin{array}{l}\text { LAA Medial wall } \\
\text { tissue Doppler } \\
\text { upward motion } \\
\text { velocity }(\mathrm{m} / \mathrm{s})\end{array}$ & $\begin{array}{l}00.14 \pm \\
00.05\end{array}$ & $0.13 \pm 0.06$ & $0.26 \pm 0.21$ & $\begin{array}{l}0.889 \\
<0.0001\end{array}$ & $<0.0001$ & $<0.0001$ \\
\hline $\begin{array}{l}\text { LAA Medial wall } \\
\text { tissue Doppler } \\
\text { downward motion } \\
\text { velocity }(\mathrm{m} / \mathrm{s})\end{array}$ & $\begin{array}{l}00.14 \pm \\
00.05\end{array}$ & $0.13 \pm 0.08$ & $0.19 \pm 0.16$ & $\begin{array}{l}0.875 \\
0.031\end{array}$ & 0.024 & 0.021 \\
\hline $\begin{array}{l}\text { LAA lateral wall } \\
\text { tissue Doppler } \\
\text { upward motion } \\
\text { velocity }(\mathrm{m} / \mathrm{s})\end{array}$ & $0.21 \pm 0.06$ & $0.20 \pm 0.18$ & $0.24 \pm 0.17$ & NS & NS & NS \\
\hline $\begin{array}{l}\text { LAA lateral wall } \\
\text { tissue Doppler } \\
\text { downward motion } \\
\text { velocity }(\mathrm{m} / \mathrm{s})\end{array}$ & $0.20 \pm 0.07$ & $0.18 \pm 0.21$ & $0.21 \pm 0.16$ & NS & NS & NS \\
\hline
\end{tabular}

\section{Orifice diameter and depth of the LAA}

The orifice diameter of LAA differed significantly between groups $(A)$ and $(C)(p=0.001)$; and groups $(B)$ and $(C)(p<0.0001)$ but no significant difference between groups $(A)$ and $(B)(p=0.089)$. Stroke patients with $A F$ had the highest mean diameter followed by stroke patients with sinus rhythm and finally, control patients.

The length of LAA depth differed significantly between group $(B)$ and $(C)(p=0.004)$ and between group $(A)$ and $(C)(p=0.049)$ but not between group $(A)$ and $(B)(p=0.351)$. Stroke patients with AF had the highest mean LAA depth length followed by stroke patients with sinus rhythm and finally, control patients.

\section{Pulsed wave doppler}

\section{Pulsed wave emptying velocity}

There was a significant difference in pulsedwave emptying velocity of LAA flow between groups $(B)$ and $(A)(p=0.001)$ and groups $(B)$ and $(C)(p<0.001)$, 
but not between groups $(A)$ and $(C)(p=0.919)$. Stroke patients with AF had the lowest mean emptying velocity followed by stroke patients with sinus rhythm and finally, control patients.

\section{Pulsed wave filling velocity of LAA flow}

A significant difference was detected between groups $(B)$ and $(A)(p<0.0001)$ and groups $(B)$ and $(C)$ $(p<0.0001)$, but not between groups $(A)$ and $(C)(p=$ 0.081). Stroke patients with AF had the lowest mean filling velocity followed by Stroke patients with sinus rhythm and finally, control patients.

\section{Tissue doppler on LAA walls}

Tissue doppler upward motion velocity of medial wall of $L A A$

The difference was significant between group $(B)$ and $(C)(p<0.0001)$ and group $(A)$ and $(C)(p<$ $0.0001)$ but not between group $(A)$ and $(B)(p=0.889)$. Stroke patients with AF had the lowest mean medial wall upward motion velocity followed by stroke patients with sinus rhythm and finally, control patients.

\section{Tissue doppler downward motion velocity of} medial wall of $L A A$

There was a significant difference between group $(B)$ and $(C)(p=0.024)$ and group $(A)$ and $(C)(p$ $=0.082)$ but not between group $(A)$ and $(B)(p=0.875)$. Stroke patients with AF had the lowest mean medial wall upward motion velocity followed by stroke patients with sinus rhythm and finally, control patients.

\section{Tissue Doppler on the lateral wall of $L A A$}

The difference was not significant between our groups as regard both upward and downward motion velocities.

Sensitivity and specificity of LAA parameters in the prediction of stroke occurrence were calculated. In patients with larger LAA orifice diameter $>1.47 \mathrm{~cm}$ $(95 \% \mathrm{Cl}$ with mean value $0.794 \mathrm{~cm}(0.709-0.878 \mathrm{~cm})$, $\mathrm{p}<0.0001)$, patients with larger LAA longitudinal length $>2.52 \mathrm{~cm}(95 \% \mathrm{Cl}$ with mean value $0.629 \mathrm{~cm}(0.521-$ $0.738 \mathrm{~cm} / \mathrm{s}), p<0.021 \mathrm{~cm})$, patients with lower LAA pulsed wave filling velocity $<0.44 \mathrm{~m} / \mathrm{s}(95 \% \mathrm{Cl}$ with mean value. $44 \mathrm{~m} / \mathrm{s}(0.701-0.863 \mathrm{~m} / \mathrm{s}), p<0.0001)$ and patients with lower LAA medial wall tissue Doppler upward motion $<0.21 \mathrm{~m} / \mathrm{s}(95 \% \mathrm{Cl}$ with mean value $0.668 \mathrm{~m} / \mathrm{s}(0.550-0.785 \mathrm{~m} / \mathrm{s}), \mathrm{p}<0.003)$ had greater stroke incidence (Table 3 and Figure 1).

Prevalence of abnormal TEE findings which constitute risk factors of stroke that could not be detected by TTE was higher in Group B (30\%) in the form of LAA
Table 3: Sensitivity and specificity of LAA parameters in prediction of stroke occurrence

\begin{tabular}{|c|c|c|c|c|c|}
\hline Parameters & AUC $(95 \% \mathrm{Cl})$ & $p$-value & Cut-off point & Sensitivity & Specificity \\
\hline Orifice diameter & $\begin{array}{l}0.794 \\
(0.709-0.878)\end{array}$ & $\begin{array}{l}< \\
0.0001\end{array}$ & $1.47 \mathrm{~cm}$ & 72.5 & 80 \\
\hline Longitudinal length & $\begin{array}{l}0.629 \\
(0.521-0.738)\end{array}$ & 0.021 & $2.52 \mathrm{~cm}$ & 61.3 & 70 \\
\hline $\begin{array}{l}\text { Pulsed wave filling } \\
\text { velocity of LAA flow }\end{array}$ & $\begin{array}{l}0.782 \\
(0.701-0.863)\end{array}$ & $<0.0001$ & $0.44 \mathrm{~m} / \mathrm{s}$ & 73.8 & 80 \\
\hline $\begin{array}{l}\text { LAA medial wall tissue } \\
\text { Doppler upward } \\
\text { motion }\end{array}$ & $\begin{array}{l}0.668 \\
(0.550-0.785)\end{array}$ & 0.003 & $0.21 \mathrm{~m} / \mathrm{s}$ & 85 & 52.5 \\
\hline
\end{tabular}

thrombus $(10 \%)$ and spontaneous echo contrast (20\%) but lower in Group A $(12.5 \%)$ in the form of patent foramen ovale (PFO) (5\%), atrial septal defect (ASD) $(2.5 \%)$, significant atherosclerotic aorta $(2.5 \%)$ (Table 4).

Table 4: Abnormal TEE findings

\begin{tabular}{|c|c|c|c|}
\hline \multirow[t]{2}{*}{ Other echo findings } & Group A (No. 40) & Group B (No. 40) & \multirow[t]{2}{*}{$\mathrm{p}$-value } \\
\hline & $\%(\mathrm{n})$ & $\%(\mathrm{n})$ & \\
\hline \multicolumn{4}{|l|}{ Presence of other findings } \\
\hline Yes & $12.5(5)$ & $30(12)$ & \multirow[t]{2}{*}{0.363} \\
\hline No & $87.5(35)$ & $70(28)$ & \\
\hline \multicolumn{4}{|l|}{ Findings } \\
\hline ASD & $2.5(1)$ & $0(0)$ & \\
\hline Atherosclerotic aorta & $2.5(1)$ & $0(0)$ & \\
\hline PFO & $5.0(2)$ & $0(0)$ & \\
\hline $\begin{array}{l}\text { LAA spontaneous } \\
\text { echo contrast }\end{array}$ & $0.0(0)$ & $20(8)$ & \\
\hline LAA thrombus & $0.0(0)$ & $10(4)$ & \\
\hline
\end{tabular}

\section{Discussion}

Our study revealed that patients with stroke in $\mathrm{AF}$ as well as sinus rhythm had significantly larger orifice diameter than control patients. The difference was not statistically significant between patients with stroke in AF and sinus rhythm though it has been higher in patients with AF.

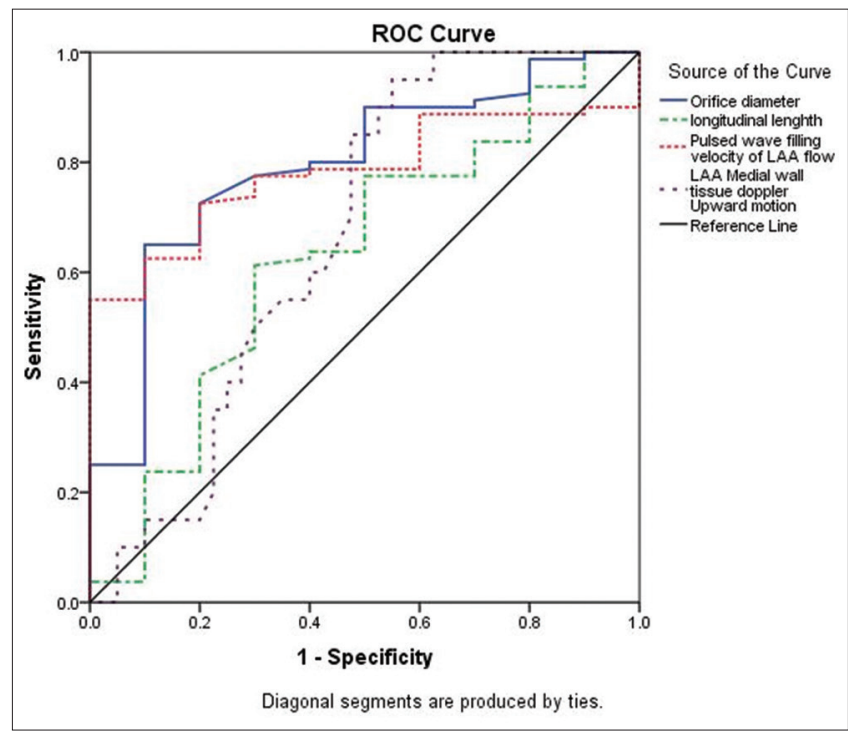

Figure 1: Left atrial appendage parameters by transesophageal echocardiography

Concordant with our results, Lee JM and colleagues also reported a negative relation between the diameter 
of the LAA orifice and velocity of blood flow, and a bigger orifice diameter was related to strokes [9]. Chen et al. and colleagues also found that a bigger diameter of LAA orifice has significant relation to stroke risk in patients with nonvalvular AF [10].

The length of LAA depth was different significantly between patients with stroke in AF $(p=0.004)$ and patients with stroke in sinus rhythm $(p=0.049)$ compared to control patients. Beinart et al. reported that the mean LAA depth was higher in patients who had stroke or TIA in comparison to patients with no history of previous embolizations [11] and this agrees with our results. Chen et al. and colleagues also reported that the LAA depth was increased in thromboembolic non-valvular AF patients [10].

Regarding pulsed-wave emptying and filling velocities of LAA flow; we proved that stroked AF patients had the least mean LAA pulsed-wave velocities which were significantly different from stroked sinus rhythm patients and patients in the control group. Stroked sinus rhythm patients had also lower emptying and filling velocities than the control patients, though not statistically significant.

This finding comes with Ariyama et al. and colleagues who tested the predictive qualities LAA wall-motion velocity for the recurrence of AF 1 year after catheter ablation in patients with nonparoxysmal AF and found that the emptying and filling velocities of the LAA was slower within the AF group than in the sinus rhythm group [12]. Also, Lee et al. and colleagues found that AF patients and stroke had a slower LAA flow velocity than patients with stroke and sinus rhythm [9]. Regarding LAA medial wall tissue doppler upward and downward motion velocities, there were significantly lower upward and downward motion velocities in sinus rhythm stroked patients than the control group and even more in AF stroked patients compared to the control. This is concordant with Ariyama et al. and colleagues who found that the LAA medial wall tissue doppler upward and downward motion velocities were higher with a significant difference in AF patients than sinus rhythm patients [12]. Regarding tissue doppler on the lateral wall of LAA; the difference was not significant between our groups regarding both upward and downward motion velocities. This is concordant with Ariyama et al. and colleagues who also found no significant difference between patients with $A F$ and patients with sinus rhythm regarding tissue Doppler on the lateral wall of LAA either upward or downward motion velocities [12].

The study showed that stroke recurrence was higher significantly in AF patients and this comes in agreement with $\mathrm{Xu}$ et al. and colleagues [13] who reported that AF augmented the chance of stroke recurrence.

Sensitivity and specificity of LAA parameters in prediction of stroke occurrence were calculated from the study results and revealed that in patients with larger LAA orifice diameter $>1.47 \mathrm{~cm}(95 \% \mathrm{Cl} 0.709-0.878$, $\mathrm{p}<0.0001$ ), patients with larger LAA longitudinal length $>2.52 \mathrm{~cm}$ (95\% Cl 0.521-0.738, p < 0.021), patients with lower LAA pulsed wave filling velocity $<0.44 \mathrm{~m} / \mathrm{s}$ (95\% Cl 0.701-0.863, $p<0.0001)$ and patients with lower LAA medial wall tissue Doppler upward motion $<0.21 \mathrm{~m} / \mathrm{s}$ (95\% Cl 0.550-0.785, p < 0.003) had greater stroke incidence.

TEE was beneficial in the detection of other abnormal TEE findings which constitute risk factors of stroke that could not be detected by TTE. These were higher in stroke patients with $\mathrm{AF}(30 \%)$ as LAA thrombus (10\%), spontaneous echo contrast (20\%) when compared to stroked sinus rhythm patients $(12.5 \%)$ PFO (5\%), ASD (2.5\%), atherosclerotic aorta $(2.5 \%)$ and vegetations on mitral valve $(2.5 \%)$. In agreement with our study, these findings were evidenced as risk factors of stroke in numerous studies as: atherosclerotic aorta [14]; vegetations on mitral valve [15]; PFO [16]; and ASD [17].

Regarding thrombus burden, we detected that stroked AF patients had a higher risk of developing thrombi and spontaneous echo contrast than stroked sinus rhythm patients. LAA was the main site of developing thrombus in our studied patients and was detected only by TEE. This is in agreement with Yaghi et al. and colleagues who studied more than three hundred AF patients and an acute embolic event by TEE and located that about one fourth of patients had thrombus evidence, and all were within the LAA [18].

\section{Conclusion}

Occult LAA thrombosis, spontaneous echo contrast as well as reduced emptying and filling velocities of LAA were found to augment the chance of cardioembolic strokes in AF patients. Reduced blood flow parameters in LAA were detected in stroked AF patients and sinus rhythm patients including dilated LAA orifice diameter increased LAA length and reduced upward and downward motion velocities of the medial wall of LAA. TEE is better than TTE in the detection of probable risk factors of stroke as PFO, ASD, vegetations, atherosclerotic aorta, and LAA thrombus.

\section{Recommendations}

We recommend TEE use for all cryptogenic stroke patients with the assessment of LAA parameters associated with cardio embolization which will affect the treatment strategy of these patients and further 
studies including larger patients' numbers to verify the TEE role in those patients are recommended. Further studies to evaluate LAA parameters in patients who were excluded from our study as patients with cardiomyopathy and valvular lesions are also recommended.

\section{Limitations}

Relatively small study population size. Some patients refused the TEE study and a few were uncooperative. The exclusion of the enormous number of high-risk patients (cardiomyopathic patients and patients with valvular lesions) may affect the obtained results. Patients were not followed up to assess the importance of our study parameters on stroke recurrence.

\section{Declarations}

\section{Ethics approval and consent to participate}

Study approval was obtained from the ethical review committee of the Faculty of Medicine, Fayoum University, Egypt in January 2018 prior to the study conduction and an informed written consent was obtained from each patient according to the rules of the Local Ethical Committee (Committee reference number: not applicable).

\section{Availability of data and materials}

The data sets used and/or analyzed during the current study available from the corresponding author on reasonable request.

\section{Authors' contributions}

GA was involved in analyzing the data and in preparing and editing the manuscript. OM was involved in analyzing the data. MA was involved in collecting and analyzing the data. TA was involved in collecting analyzing the data. All authors have read and approved the manuscript.

\section{References}

1. Krishnamurthi RV, Feigin VL, Forouzanfar MH, Mensah GA Connor M, Bennett DA, et al. Global and regional burden of firstever ischaemic and haemorrhagic stroke during 1990-2010: Findings from the global burden of disease study 2010. Lancet Glob Health. 2013;383(9913):218. https://doi.org/10.1016/ s0140-6736(13)61953-4

2. Go AS, Hylek EM, Phillips KA, Chang Y, Henault LE, Selby JV, et al. Prevalence of diagnosed atrial fibrillation in adults: National implications for rhythm management and stroke prevention: The anticoagulation and risk factors in atrial fibrillation (ATRIA) Study. JAMA. 2001;285(18):2370-5. https://doi.org/10.1001/ jama.285.18.2370

PMid: 11343485

3. de Bruijn SF, Agema WR, Lammers GJ, van der Wall EE, Wolterbeek R, Holman ER, et al. Transesophageal echocardiography is superior to transthoracic echocardiography in management of patients of any age with transient ischemic attack or stroke. Stroke. 2006;37(10):2531-4. https://doi. org/10.1161/01.str.0000241064.46659.69

PMid:16946152

4. Vanassche T, Lauw MN, Eikelboom JW, Healey JS, Hart RG, Alings $\mathrm{M}$, et al. Risk of ischaemic stroke according to pattern of atrial fibrillation: Analysis of 6563 aspirin-treated patients in ACTIVE-A and AVERROES. Eur Heart J. 2015;36(5):281-7a. https://doi.org/10.1093/eurheartj/ehu307

PMid:25187524

5. Chao TF, Liu CJ, Chen SJ, Wang KL, Lin YJ, Chang SL, et al. Atrial fibrillation and the risk of ischemic stroke: Does it still matter in patients with a CHA2DS2-VASc score of 0 or 1? Stroke. 2012;43(10):2551-5. https://doi.org/10.1161/ strokeaha.112.667865

PMid:22871677

6. Nucifora G, Faletra FF, Regoli F, Pasotti E, Pedrazzini G, Moccetti $T$, et al. Evaluation of the left atrial appendage with real-time 3-dimensional transesophageal echocardiography: Implications for catheter-based left atrial appendage closure. Circ Cardiovasc Imaging. 2011;4(5):514-23. https://doi. org/10.1161/circimaging. 111.963892

PMid:21737601

7. Sallach JA, Puwanant S, Drinko JK, Jaffer S, Donal E, Thambidorai SK, et al. Comprehensive left atrial appendage optimization of thrombus using surface echocardiography: The CLOTS multicenter pilot trial. J Am Soc Echocardiogr. 2009;22(10):1165-72. https://doi.org/10.1016/j.echo.2009.05.028 PMid:19647401

8. Ono K, Iwama M, Kawasaki M, Tanaka R, Watanabe T Onishi $\mathrm{N}$, et al. Motion of left atrial appendage as a determinant of thrombus formation in patients with a low CHADS2 score receiving warfarin for persistent nonvalvular atrial fibrillation. Cardiovasc Ultrasound. 2012;10:50. https://doi. org/10.1186/1476-7120-10-50

PMid:23270370

9. Lee JM, Shim J, Uhm JS, Kim YJ, Lee HJ, Pak HN, et al Impact of increased orifice size and decreased flow velocity of left atrial appendage on stroke in nonvalvular atrial fibrillation. Am J Cardiol. 2014;113(6):963-9. https://doi.org/10.1016/j. amjcard.2013.11.058

PMid:24462064

10. Chen Z, Bai W, Li C, Wang H, Tang H, Qin $Y$, et al. Left atria appendage parameters assessed by real-time three-dimensional transesophageal echocardiography predict thromboembolic risk in patients with nonvalvular atrial fibrillation. J Ultrasound Med. 2017;36(6):1119-28. https://doi.org/10.7863/ultra.16.05070 PMid:28233335

11. Beinart R, Heist K, Newell JB, Holmvang G, Ruskin JN, Mansour M. Left atrial appendage dimensions predict the risk of stroke/TIA in patients with atrial fibrillation. J Cardiovasc Electrophysiol. 2011;22(1):10-5. https://doi. org/10.1111/j.1540-8167.2010.01854.x

PMid:20662984

12. Ariyama $M$, Kato $S$, Matsumura $M$, Yoshimoto $H$, Nakajima $Y$ Nakano $\mathrm{S}$, et al. Left atrial appendage wall-motion velocity associates with recurrence of nonparoxysmal atrial fibrillation 
after catheter ablation. Echocardiography. 2014;32(2):272-80. https://doi.org/10.1111/echo.12647

PMid:24919546

13. Xu G, Liu X, Wu W, Zhang R, Yin Q. Recurrence after ischemic stroke in Chinese patients: Impact of uncontrolled modifiable risk factors. Cerebrovasc Dis. 2007;23(2-3):117-20. https://doi. org/10.1159/000097047

PMid: 17124391

14. Wehrum $T$, Dragonu L, Strecker $C$, Schuchardt F, Hennemuth $A$, Drexl J, et al. Aortic atheroma as a source of stroke-assessment of embolization risk using $3 \mathrm{D}$ CMR in stroke patients and controls. J Cardiovasc Magn Reson. 2017;19(1):67. https://doi. org/10.1186/s12968-017-0379-x

PMid:28877718

15. Merkler AE, Chu SY, Lerario MP, Navi BB, Kamel H.
Temporal relationship between infective endocarditis and stroke. Neurology. 2015;85(6):512-6. https://doi.org/10.1212/ wnl.0000000000001835

PMid:26163428

16. Sun YP, Homma S. Patent foramen Ovale and stroke. Circ J. 2016;80(8)1665-73. https://doi.org/10.1253/circj.cj-16-0534 PMid:27334127

17. Leppert M, Poisson SN, Carrolk JD. Atrial septal defects and cardio embolic strokes. Cardiol Clin. 2016;34(2):225-30. PMid:27150170

18. Yaghi S, Son C, Gray WA, Furie KL, Elkind MS, Kamel H. Left atrial appendage function and stroke risk. Stroke. 2015;46(12):35549. https://doi.org/10.1161/strokeaha.115.011273

PMid:26508750 